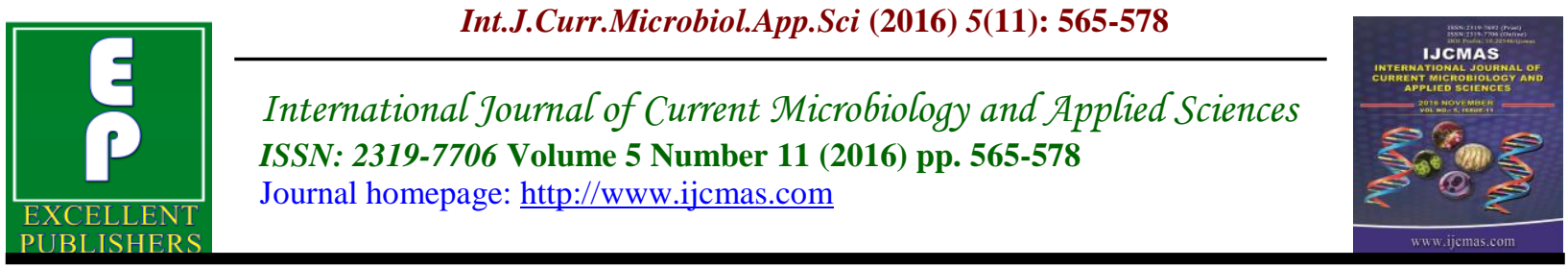

Original Research Article

http://dx.doi.org/10.20546/ijcmas.2016.511.067

\title{
Biodegradation of Reactive Red-11 by the Isolate Enterococcus casseliflavus CMGS-1 Strain
}

\author{
Madhuri R. Basutkar ${ }^{1}$, Channappa T. Shivannavar ${ }^{1 *}$ and Subhaschandra M. Gaddad \\ Department of Post Graduate Studies and Research in Microbiology, \\ Gulbarga University, Kalaburagi, India \\ *Corresponding author
}

\begin{abstract}
A B S T R A C T
Keywords

Potential,

Enterococcus

casseliflavus,

FT-IR spectrum,

MTCC, IMTECH.

\begin{tabular}{l}
\hline Article Info \\
\hline Accepted: \\
24 October 2016 \\
Available Online: \\
10 November 2016
\end{tabular}

The study was designed to isolate a potential dye degrading novel isolate, which is capable degrading wide range of textile dyes. In this direction a isolate identified as Enterococcus casseliflavus strain isolated from textile treatment unit, showed decolorisation of $98.91 \%$ in mineral salt medium blended with $200 \mathrm{mg} / \mathrm{L}$ reactive red-11 as sole source carbon within 72 hours of duration, and to optimized the decolorisation capacity of isolate, various abiotic and biotic parameters were framed, finally organism showed $96.56 \%$ decolorisation of $400 \mathrm{mg} / \mathrm{L}$ reactive red11 , at $\mathrm{pH}-9$, temperature $40^{\circ} \mathrm{C}$, inoculum concentration $5 \mathrm{ml}$, and yeast extract $1 \mathrm{gm} / \mathrm{L}$ at 16 hours of duration. The complete degradation was confirmed by FT-IR spectrum analysis and strain was preserved in MTCC (IMTECH) with MTCC no:12538.
\end{abstract}

\section{Introduction}

Pollutions are the insertion of contaminations, in the natural environments leads to various obstructions, in water pollutants synthetic dye pollution emerging rapidly. In Asia, India may become second major contributor of textile waste water discharging (Verma et al., 2012). The basic structure constituent of dyes are contains $\mathrm{n}=\mathrm{n}$ bonds, attached to a benzene ring, and various other compounds like $\mathrm{SO}_{3} \mathrm{H}$, $\mathrm{SO}_{2} \mathrm{NH}_{2}, \quad \mathrm{NO}_{2}$ Attached to a aromatic nucleus (Jain et al., 2012). Various physical, chemical methods like reverse osmosis, Fenton's reagent, chemical flocculation, ion exchange, coagulation, are available but these methods are expensive leads secondary sludge generation and complete degradation cannot be achieved (Jadhav et al., 2012). More than 10000 different kinds of dyes are available in world (Kadam et al., 2011). These dyes are carcinogenic, toxic, and mutagenic in nature. (Shah et al., 2013). The ultimate solution we will get from microorganisms, these are the natural cleaners of the nature. In these direction we selected the potential strain which having the capacity to degrade reactive red-11, confirmed by the FT-IR analysis.

\section{Materials and Methods}

Sources of sample: Soil and effluent samples were collected from the textile 
industrial areas and textile dye treatment unit (MRDC) of Sholapur Maharashtra.

Dye:- Reactive red-11 procured from the Colorise, Heena textile industries. Gujarat (India).

\section{Information and molecular Structure of Reactive red-11}

Presently work carried in the degradation of synthetic Reactive red -11 dye, used mainly in the dying of cotton, viscose fabric and silk, in printing. Its properties are- single azo $(\mathrm{n}=\mathrm{n})$ bonded chromopheric group, having Chlorine, $\mathrm{SO} 3 \mathrm{OH}, \mathrm{NO} 2$, as reactive group attached with benzene rings. It is having molecular weight -681.33 with a $\lambda \max 540 \mathrm{~nm}$, molecular formula: C20H9Cl2N6Na3O9S2. CAS Registry Number: 12226083. Manufacturing Method is: - 4Aminobenzoicacid diazo, in alkaline conditions and 4Amino5hydroxynaphthalene2, 7 disulfonicacid coupling, again with 2, 4, 6Trichloro1, 3,5triazine condensation.

\section{Structure of reactive red-11}<smiles>NOC(=O)c1ccc(N=Nc2c(S(N)(=O)=O)cc3cc(S(N)(=O)=O)cc(Nc4nc(Cl)nc(Cl)n4)c3c2O)cc1</smiles>

\section{Chemicals}

The chemicals and solvents used in this work were of analytical grade and procured from standard companies like HI-media Pvt.Ltd. Mumbai. Sugar utilization tests were performed by using Hi-Carbo kit.

\section{Mineral Salt Medium (MSM)}

The mineral salt medium (MSM) broth was prepared by adding $\mathrm{Na}_{2} \mathrm{HPO}_{4} .2 \mathrm{H}_{2} \mathrm{O}-12.00$ g, KH2PO4 -2.00 g, $\mathrm{NH}_{4} \mathrm{NO}_{3}-0.50$ g, $\mathrm{MgCl}_{2} .6 \mathrm{H}_{2} \mathrm{O}-0.10 \mathrm{~g}, \mathrm{Ca}\left(\mathrm{NO}_{3}\right)_{2} .4 \mathrm{H}_{2} \mathrm{O}-$ $50.00 \mathrm{mg}, \mathrm{FeCl}_{2} .4 \mathrm{H}_{2} \mathrm{O}-7.50 \mathrm{mg}$ to $1000 \mathrm{ml}$ of distilled water and to this $10 \mathrm{ml}$ of trace elements solution was added before adjusted the $\mathrm{pH}$ 7.0. Trace elements solution was prepared by adding $\mathrm{FeSO}_{4} .7 \mathrm{H}_{2} \mathrm{O}-0.10 \mathrm{~g}$, $\mathrm{ZnSO}_{4} .7 \mathrm{H}_{2} \mathrm{O}-0.10 \mathrm{~g}, \quad \mathrm{CuSO}_{4} .5 \mathrm{H}_{2} \mathrm{O}-0.1 \mathrm{~g}$, $\mathrm{CaCl}_{2} \cdot 6 \mathrm{H}_{2} \mathrm{O}-0.1 \mathrm{~g}, \mathrm{MnSO}_{4} \cdot \mathrm{H}_{2} \mathrm{O}-0.17 \mathrm{~g}$ to
$1000 \mathrm{ml}$ of distilled water and $10 \mathrm{ml}$ of trace element solution added MSM, finally media were sterilized at $121^{\circ} \mathrm{C}$ for $15 \mathrm{~min}$ before use (Usha et al., 2012).

Preparations of samples and isolation, screening of RR-11 decolorizing bacterial strain

10grams of soil sample weighed and water $10 \mathrm{ml}$ of water sample poured into the $100 \mathrm{ml}$ of $0.8 \%$ saline solution and kept on the rotary shaker at $150 \mathrm{rpm}$ for the duration of one hour. After one hour flasks were taken the rotary shaker, left for the soil settlement. And carefully $20 \mathrm{ml}$ of supernatant was added in the $50 \mathrm{mg} / \mathrm{L}$ RR-11 + MS Broth ,kept for the observation in the static condition routinely decolorisation were checked at $540 \mathrm{~nm}$ using UV-VIS Spectrophotometer, flasks showing more 
than $50 \%$ of the decolorisation supernatant transferred to the fresh MS Broth+50mg/L RR-11 dye as the sole source of carbon. The flask showing fastest decolorisation were selected and loopful of culture were streaked on the MSM+50mg/L RR-11 dye as the sole source, the colonies were showing zones were selected for the screening,

One set of pure culture of dye decolorizing bacterial strains were selected and sub cultured on nutrient agar slants and stored in refrigerator with $25 \%$ sterile glycerol. Another set was used for the screening of the decolorisation pure culture was grown in the nutrient broth and $10 \mathrm{ml}$ of $\mathrm{NB}$ was added to the $100 \mathrm{ml} \mathrm{MS}$ Broth+ $100 \mathrm{mg} / \mathrm{L}$ RR-11 observation was done routinely.

Decolorisation assay:- It was studied in two different ways one with decolorisation in dye as the sole source of carbon and with $1 \mathrm{gm} / \mathrm{L}$ yeast extract as the additional nutrient source. The bacterial isolates were showing the fastest rate of decolorisation within shorter duration of time was selected, in MSBroth+100mg/L RR-11, out of other isolates, a bacterial strain designated AS CMGS-1, was selected which was decolorizing the $200 \mathrm{mg} / \mathrm{L}$ RR-11 within 72 hours, and in yeast extract was $400 \mathrm{mg} / \mathrm{L}$ was the optimum, The flasks were incubated at $35^{0} \mathrm{C}$. To determine rate of decolorization every 4 hour $3 \mathrm{ml}$ of the sample was drawn from each flask and centrifuged at 10,000 rpm for $10 \mathrm{~min}$ then supernatant used for taking optical density at $540 \mathrm{~nm}$ in a UVVis spectrophotometer. .A decrease in the optical density compared to control was taken as an indication of decolorization The decolorization medium without culture served as control, in 16 hours of incubation isolate CMGS-1, showing $95.9 \%$ of decolorisation which is selected by final conformation using To know decolorization is due to change in the $\mathrm{pH}$, the culture filtrate was checked for alteration in the initial $\mathrm{pH}$, if so; again check the color change in supernatant by adding $\mathrm{HCl}$ or $\mathrm{NaOH}$. The decolorization is due to adsorption was tested by dissolving the culture pellet in the solvent. Similarly absorption was performed by analyzing the dye in the cell lysate.

Decolorization procedure: Dye decolorisation in MS broth supplemented with yeast extract $(0.1 \% \mathrm{w} / \mathrm{v})$ and reactive red-11 (400mg/L) complete decolorisation of dye occurred within 16 hours of duration. Dye decolorization was confirmed by the checking optical density at $540 \mathrm{~nm}$ for different intervals of time. The percentage of decolorisation was calculated by following equation.

\section{Calculation of \% decolorization}

Percentage of decolorization =initial O.Dfinal-O.D X 100/initial O.D.

\section{Optimization of various abiotic and biotic factors for maximum dye decolorisation by isolated bacterium}

The abiotic factors including $\mathrm{pH}$, temperature and aeration were optimized. Using wide range of $\mathrm{pH}$ from 4-12 with an increase of $\mathrm{pH}$ values 1 at a time and temperature in the range from $20-50^{\circ} \mathrm{C}$ with $5^{0} \mathrm{C}$ (interval). For the aeriation flasks were incubated on incubator shaker with a speed of $120 \mathrm{rpm}$ and for static condition flaks were incubated in normal incubator at $35^{\circ} \mathrm{C}$. After knowing the optimum $\mathrm{pH}$ and temperature bacterial inoculums size was measured by adding 5 to $20 \%(5,10,15,20)$ to $100 \mathrm{ml}$ of $\mathrm{DM}$.

The effect of additional nitrogen nutrients on the dye degrading efficiency of isolated bacterium with all optimized conditions was 
performed by adding $1 \%$ of selected organic and inorganic nitrogen and different carbon sources to DM culture. The nutrient source showed maximum percent decolonization of RR-11 and was more than the control (culture without the additional nutrients) was selected and used for the determination of optimum concentration required for maximum decolorization by isolate. Determination of minimum yeast extract concentration required to optimize the decolorisation efficiency of an isolated bacterium was performed by adding 0.1 to $2 \%$ of yeast extract with an intervals of 0.5 $\%$.

\section{Morphological Identification}

Loopful culture of isolate CMGS-1 streaked on nutrient agar plate, after 24 hours of incubation, colonies were selected for the morphological and colony characteristics studies they are size, shape, motility, gram staining, etc

\section{Biochemical Identification}

various biochemical tests were performed to characterize the isolate CMGS-1, tests were: carbohydrate utilization tests, IMViC tests, Urease production, catalase, gelatin hydrolysis, nitrate reduction, starch hydrolysis, tests as prescribed Experiments in Microbiology, Plant Pathology and Biotechnology, (K. R. Aneja New Age International Microbiology, 2003) and Bergey's Manual of Systematic Bacteriology, second edition.

\section{Sugar Utilization Tests}

various 32 Sugar (carbohydrate) utilization tests were performed by using HI-Carbo kit (Himedia). 18 hours grown culture of isolate CMGS-1 (20 $\mu$ l using sterile pipette) was added in the each vial of sugar utilization kit, kept for the 24 hours of incubation, results were noted down.

\section{6s rRNA Identification}

Pure bacterial colonies were selected for the sequencing, sent for the identification, at Royal Life Sciences Pvt. Ltd. Hyderabad, India. The alignment of the sequences was done using CLUSTALW program V1.6 at European bioinformatics site (http://www.ebi.ac.uk/Tools/msa/). The sequence was refined manually after crosschecking with the raw data to remove ambiguities and submitted to GenBank. Evolutionary history checked by To see the Phylogenetic position of bacterial isolate using the neighbor-joining method (Saitou et al., 1987).The optimal tree with the sum of branch length $=0.28801765$ is shown. The Phylogenetic tree was linearized assuming equal evolutionary rates in all lineages (Takazeki et al., 1995). The clock calibration to convert distance to time was 0.02 (time/node height). The tree is drawn to scale, with branch lengths in the same units as those of the evolutionary distances used to infer the Phylogenetic tree. The evolutionary distances were computed using the maximum composite likelihood method (Tamura et al., 2004). and are in the units of the number of base substitutions per site. Codon positions included were $1 \mathrm{st}+2 \mathrm{nd}+$ 3rd + Noncoding. Evolutionary analyses were conducted in MEGA6 software (Koichiro Tamura et al., 2013).

\section{FT-IR Analysis Procedure}

To analyze degradation capacity of isolate CMGS-3, Reactive red-11,, and a 16 hour (400mg/L RR-11) degraded sample were sent to the Sipra Pvt Labs, Hydrabad and FT-IR analysis was done by using Fischer Scientific (Nicolet, iH5) Spectrophotometer 
and IR region of $400-4000 \mathrm{~cm}^{-1}$ with 32 scan speed.

Preparation of sample: 16 hour degraded samples were centrifuged at $10000 \mathrm{rpm}$ for 10mins duration. Above supernatant was taken, and saturated with equal volume of ethyl acetate and separated the organic phase, kept at $45 .^{\mathrm{C}}$ in thermostat incubator and observed until complete evaporation of ethyl acetate extracts. Complete air dried metabolites dissolved in methanol. After evaporation of methanol in degraded metabolites weighed and sent to the FT-IR analysis, with reactive red-11 dye as control for comparison (Bheemaraddi et al., 2014).

\section{Study of phototoxic effect on the plants}

Two widely grown agriculture plant species, Tricicum aeticum, Vigna radiate, were selected for the phototoxic study, conducted for the upto15 days of duration and observed results of the germination and plants growth. Phototoxic study divided into two ways, water as the control, through these control water germination and plant growth compared with untreated and treated metabolites of waste water sample (centrifuged at 10000rpm). Results were noted down, treated metabolites. Shown excellent results in the germination and plants growth. By these it is concludes that isolate CMGS-1 able to degrade dye completely, can be used for in the treatment of synthetic waste water treatment.

\section{Results and Discussion}

Isolate CMGS-1 was tested due to the decolorisation ability, it was isolated by the textile dye treatment solapur Maharashtra, shown $98.91 \%$,decolorisation in $200 \mathrm{mg} / \mathrm{L}$ RR-11 within 72 hours. In yeast extract was $400 \mathrm{mg} / \mathrm{L}$ was the optimum in 16 hours of the incubation.
Isolation and Characterization of Reactive Violet-1 decolorizing bacteria

The colony characteristics were studied on the nutrient agar medium, and gram positive bacteria confirmed by the gram staining process various biochemical, sugar utilization testes and 16s rRNA analysis done.

Optimization of abiotic and biotic parameters of. Enterococcus casseliflavus strain CMGS-1

Decolorization assay for determination of dye decolorizing efficiency isolate Enterococcus casseliflavus strain CMGS-1

Utilization RR-11 by an isolate CMGS-1, as a sole carbon source in mineral salt medium and with yeast extract Enterococcus casseliflavus strain CMGS-1

It shown effective decolorisation in the RR$11(200 \mathrm{mg} / \mathrm{L})$ within 72 hours of incubation and in the sam Concentration $0.1 \%$ yeast extract $(1 \mathrm{gm} / \mathrm{L})$ was added the optimum Decolorisation was noticed around $(400 \mathrm{mg} / \mathrm{L}) \quad 96.60 \%$ with 16 hours of incubation under static condition. According (Jain et al., 2012; P. S. Patil, et al., 2008) the decolorisation depends upon the structure of Dyes and metabolites produced during the decolorisation procedure. To enhance the decolorisation Capacity of isolate various abiotic and biotic parameters were programmed

Effect of static and shaking conditions:isolate CMGS-1 showed effective decolorisation in static condition. It static condition the $\%$ of decolorisation was $97.05 \%$, an d shaking it was $50.56 \%$ of decolorisation. For decolorisation isolate CMGS-1requires static condition and it is kept constant for Upcoming parameters. 


\section{Optimization of $\mathrm{pH}$ concentration}

$\mathrm{pH}$ is considered as the essential, isolate CMGS-1 shown decolorisation in all range of $\mathrm{pH}$ conditions, and effective decolorisation was observed at the $\mathrm{pH}-9$ :96.96. alkaline $\mathrm{pH}$ is the better condition for the effective decolorisation. Similar with our results (Imran et al., 2014) showed that Shewanella sps IFN4 decolorized mixed azo dyes in the $\mathrm{pH}$ range of 5-9. Decolorisation capacity depends upon organisms.

\section{Optimization of temperatures}

Isolate CMGS-1 is shown effective decolorisation in thermophillic range that is at $45^{\circ} \mathrm{C}:-97.2 \%$ decolorisation. Similar with the results (Ali et al., 2010) stated that the mesophilic range is $25^{0}-45^{\circ} \mathrm{C}$ suits for waste water treatment plants including dye effluents treatment plants in tropical conditions.

Table.1 Morphological and biochemical characteristics of Enterococcus casseliflavus strain CMGS-1

\begin{tabular}{|l|l|}
\hline Tests & Observation \\
\hline $\begin{array}{l}\text { A. Colony character } \\
\text { Size }\end{array}$ & Small \\
\hline Shape & Entire \\
\hline Color & White \\
\hline $\begin{array}{l}\text { B. Morphological Characteristics } \\
\text { Grams staining }\end{array}$ & $\begin{array}{l}\text { Blue colour cocci } \\
\text { (Positive) }\end{array}$ \\
\hline Motility & Non motile \\
\hline Cell shape and arrangement of spore & No spore former \\
\hline $\begin{array}{l}\text { C. Carbohydrate } \\
\text { Glucose }\end{array}$ & Acid production \\
\hline Sucrose & Acid production \\
\hline Lactose & Acid production \\
\hline Mannitol fermentation & $+\mathrm{ve}$ \\
\hline $\begin{array}{l}\text { D. IMViC } \\
\text { Indole }\end{array}$ & $-\mathrm{ve}$ \\
\hline Methyl Red & $+\mathrm{ve}$ \\
\hline Voges Proskaur & $+\mathrm{ve}$ \\
\hline Citrate & $-\mathrm{ve}$ \\
\hline E. Urease production & $+\mathrm{ve}$ \\
\hline F.catalase & $+\mathrm{ve}$ \\
\hline G. Gelatin hydrolysis & $-\mathrm{ve}$ \\
\hline H.Nitrate reduction & $+\mathrm{ve}$ \\
\hline I Starch hydrolysis & $-\mathrm{ve}$ \\
\hline & \\
\hline
\end{tabular}


Table.2 Sugar utilization tests

\begin{tabular}{|l|l|}
\hline Tests & Observation \\
\hline Xylose & +ve \\
\hline Maltose & +ve \\
\hline Fructose & +ve \\
\hline Dextrose & $+\mathrm{ve}$ \\
\hline Galactose & $+\mathrm{ve}$ \\
\hline Raffinose & $+\mathrm{ve}$ \\
\hline Trehalose & $+\mathrm{ve}$ \\
\hline Melibiose & $+\mathrm{ve}$ \\
\hline L-Arabionose & $+\mathrm{ve}$ \\
\hline Mannose & $+\mathrm{ve}$ \\
\hline Inulin & $+\mathrm{ve}$ \\
\hline Sodium gluconate & $+\mathrm{ve}$ \\
\hline Glycerol & $+\mathrm{ve}$ \\
\hline Salicin & $+\mathrm{ve}$ \\
\hline Dulcitol & $-\mathrm{ve}$ \\
\hline Inositol & $-\mathrm{ve}$ \\
\hline Sorbitol & $-\mathrm{ve}$ \\
\hline Adonitol & $-\mathrm{ve}$ \\
\hline Arabitol & $-\mathrm{ve}$ \\
\hline Erythritol & $-\mathrm{ve}$ \\
\hline Alpha-methyl-D-glucoside & $+\mathrm{ve}$ \\
\hline Rhamnose & $-\mathrm{ve}$ \\
\hline Cellobiose & $-\mathrm{ve}$ \\
\hline Melezitose & $-\mathrm{ve}$ \\
\hline Alpha-methyl-d-mannoside & $-\mathrm{ve}$ \\
\hline Xylitol & $-\mathrm{ve}$ \\
\hline ONPG & $+\mathrm{ve}$ \\
\hline Esculin hydrolysis & $+\mathrm{ve}$ \\
\hline d-arabinose & $-\mathrm{ve}$ \\
\hline malonate utilization & $-\mathrm{ve}$ \\
\hline Sorbose & $-\mathrm{ve}$ \\
\hline & \\
\hline
\end{tabular}


Fig.1 Phylogenetic tree of Enterococcus casseliflavus CMGS-1

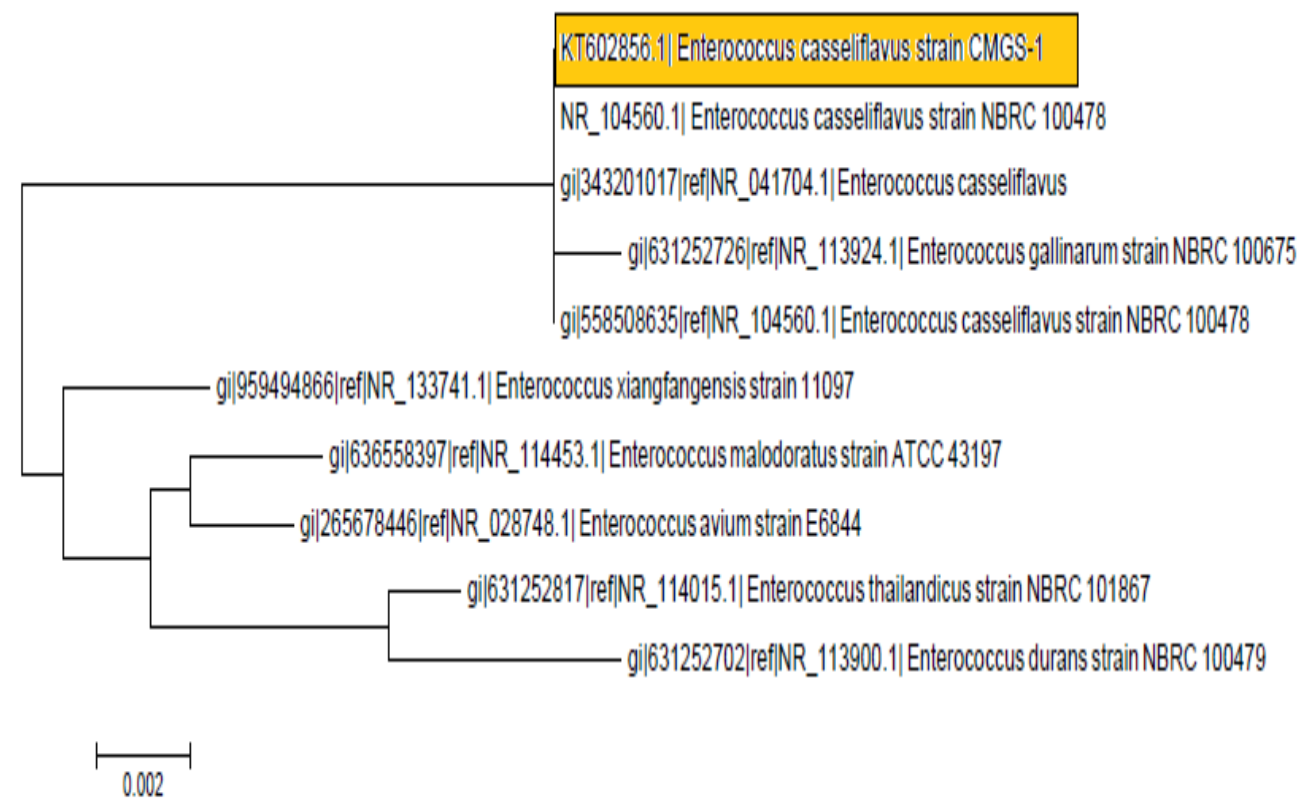

Fig.2 Colony characters on nutrient agar plate

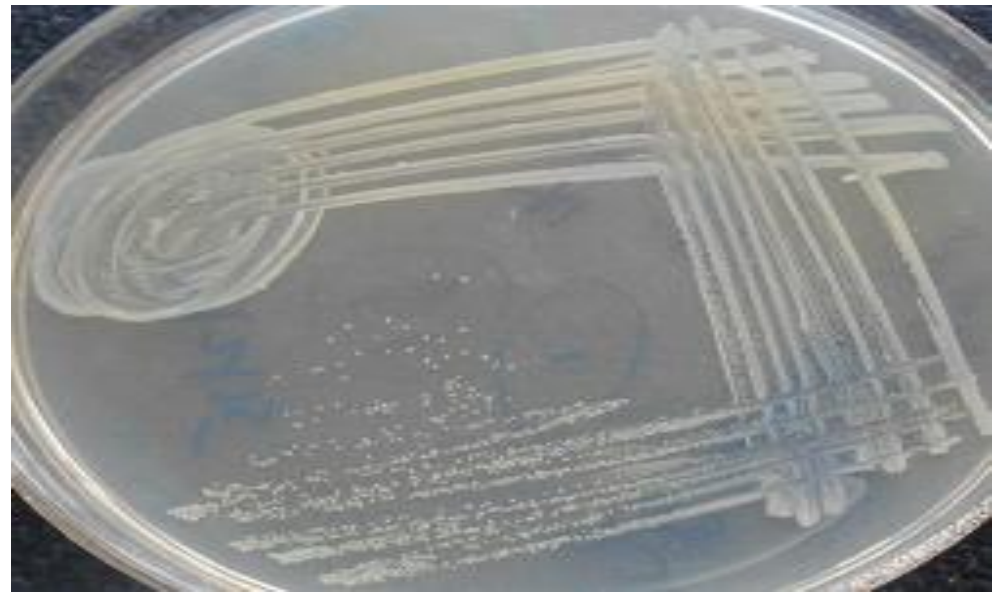

Fig.3 Gram staining image of CMGS-1

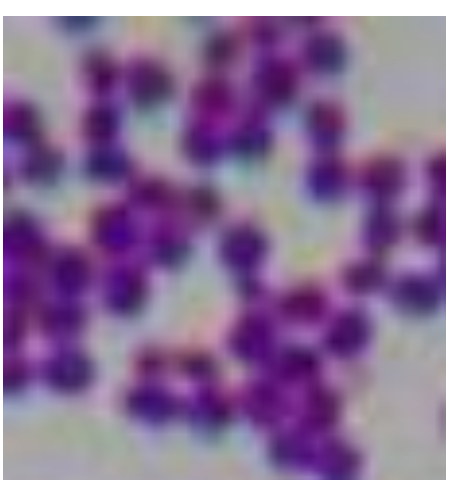


Fig.4 Optimization of decolorisation in RR-11as sole carbon source

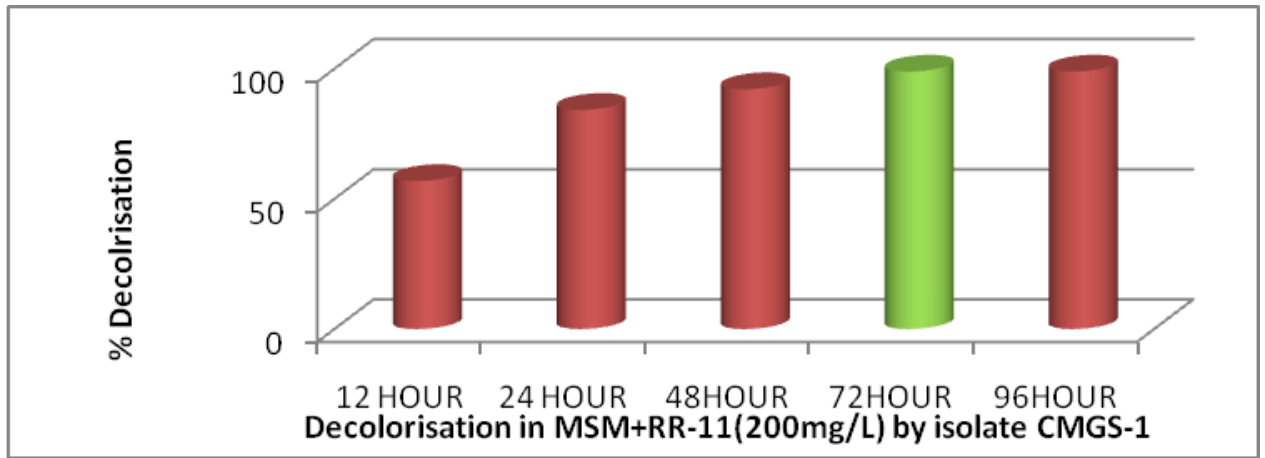

Fig.5 Optimization of decolorisation in RR-11 with $0.1 \%$ of yeast extract concentration

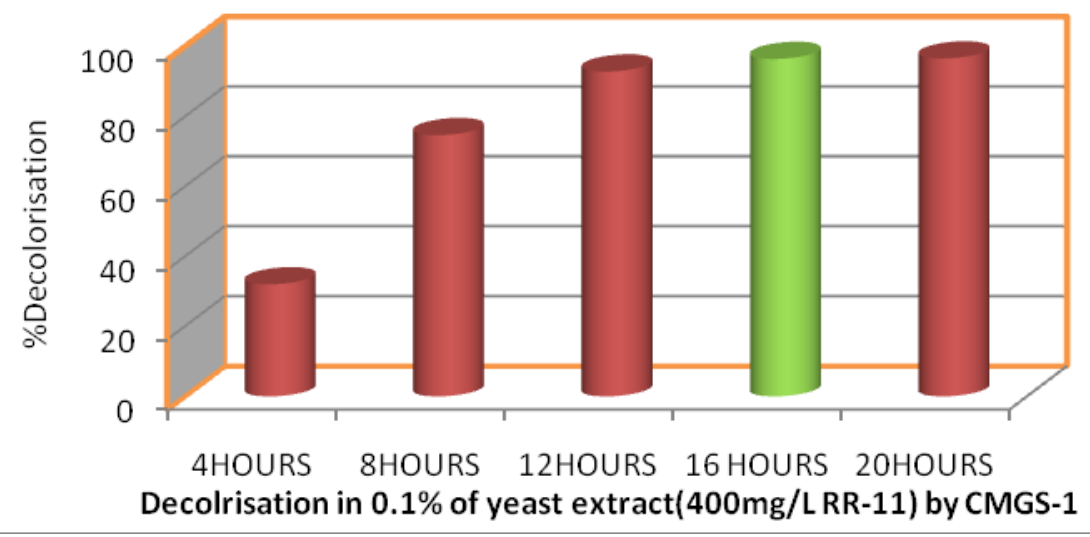

Fig.6 effect of static and shaking for maximum decolorisation by Enterococcus casseliflavus strain CMGS1

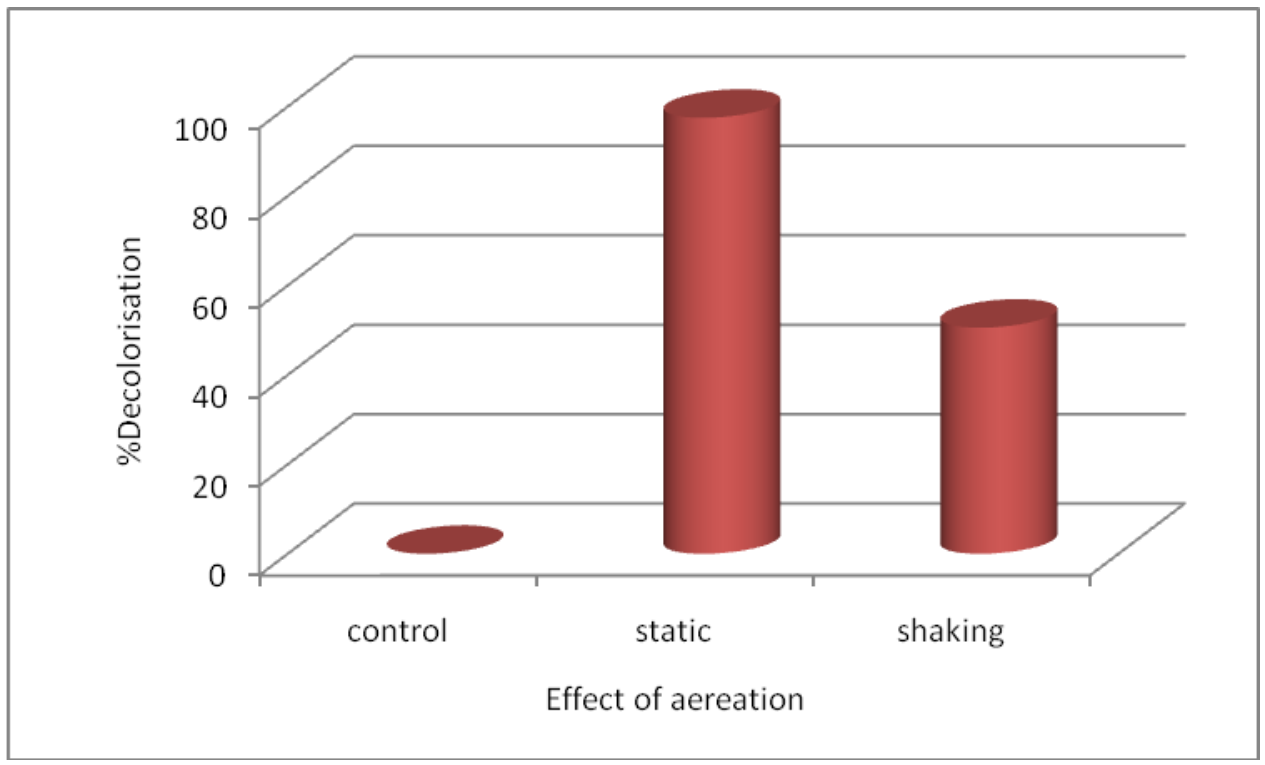


Fig.7 optimization of $\mathrm{pH}$ parameter for maximum decolorisation by Enterococcus casseliflavus strain CMGS1

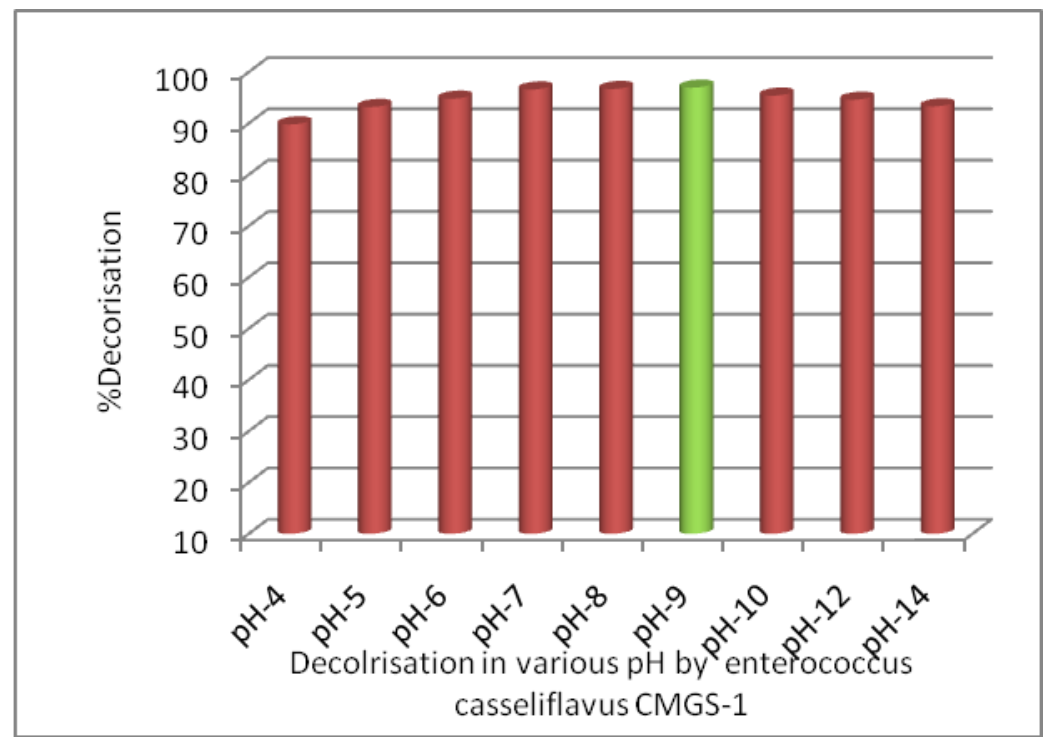

Fig.8 optimization of temperature for maximum decolorisation by Enterococcus casseliflavus strain CMGS-1

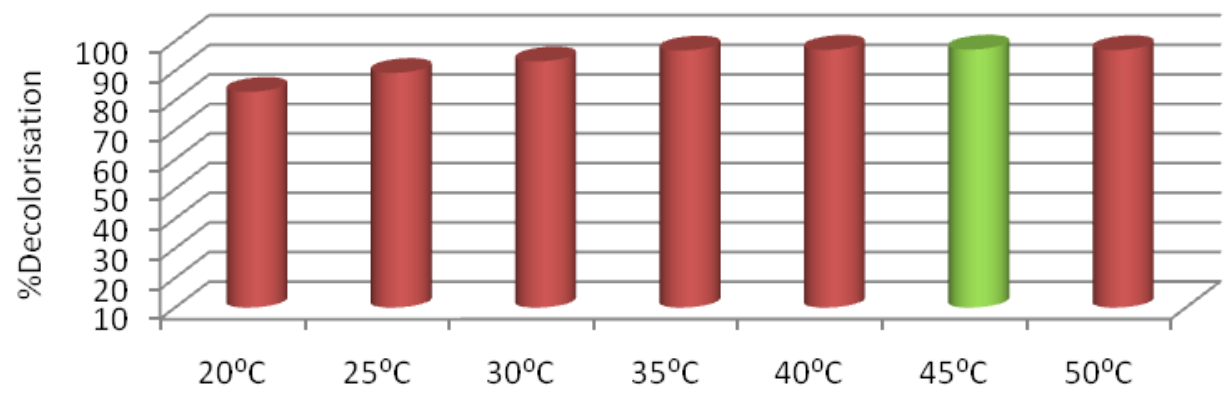

Decolorisation in different temp range by Enterococcus casseliflavus CMGS-1

Fig.9 optimization of nitrogen sources for maximum decolorisation by Enterococcus casseliflavus strain CMGS1

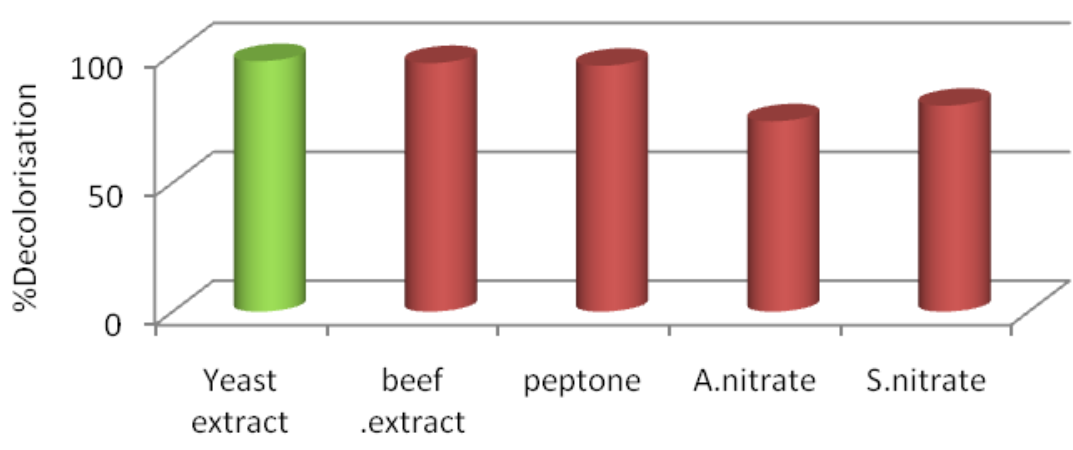

Decolorisation in different nitrogen sources range by Enterococcus casseliflavus CMGS-1 
Fig.10 optimization of inoculum size for maximum decolorisation by Enterococcus casseliflavus strain CMGS1

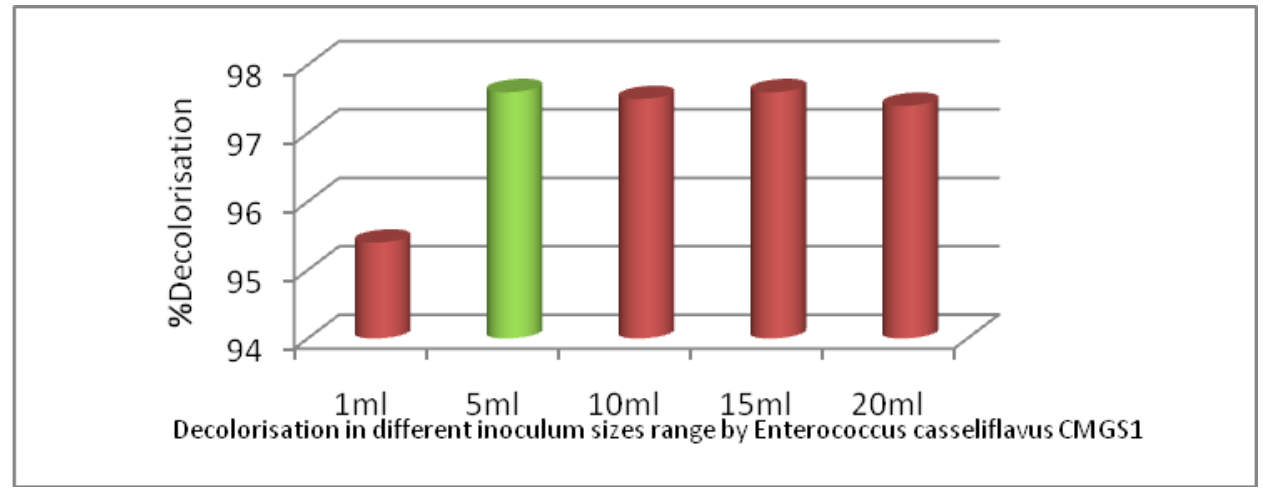

Fig.11 effect of yeast extract for maximum decolorisation by Enterococcus casseliflavus strain CMGS1

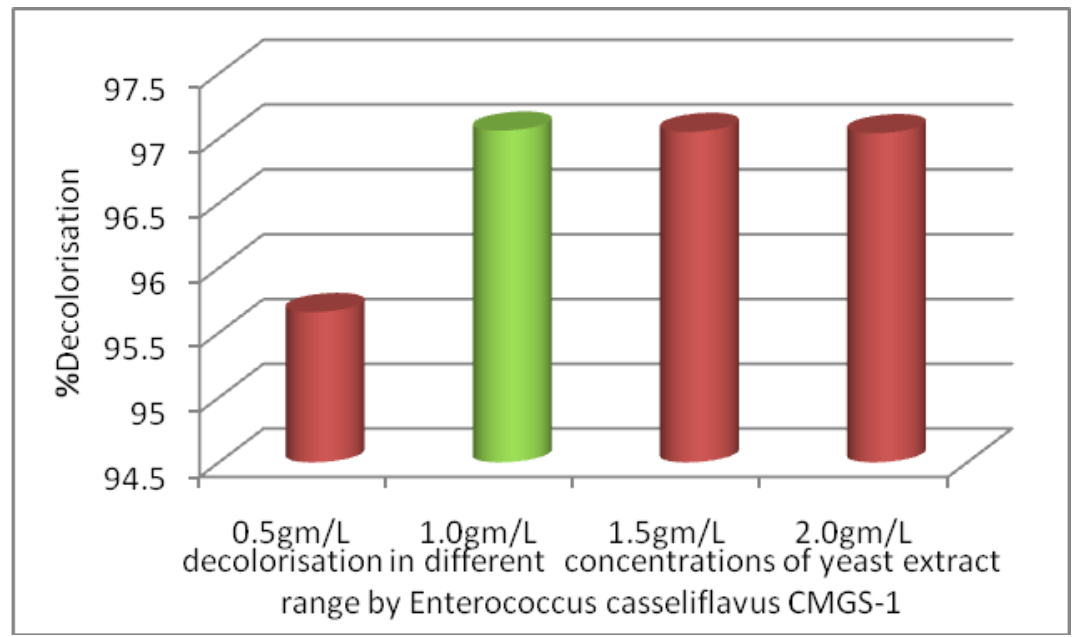

Fig.12 decolorisation in various reactive dyes by Enterococcus casseliflavus strain CMGS1

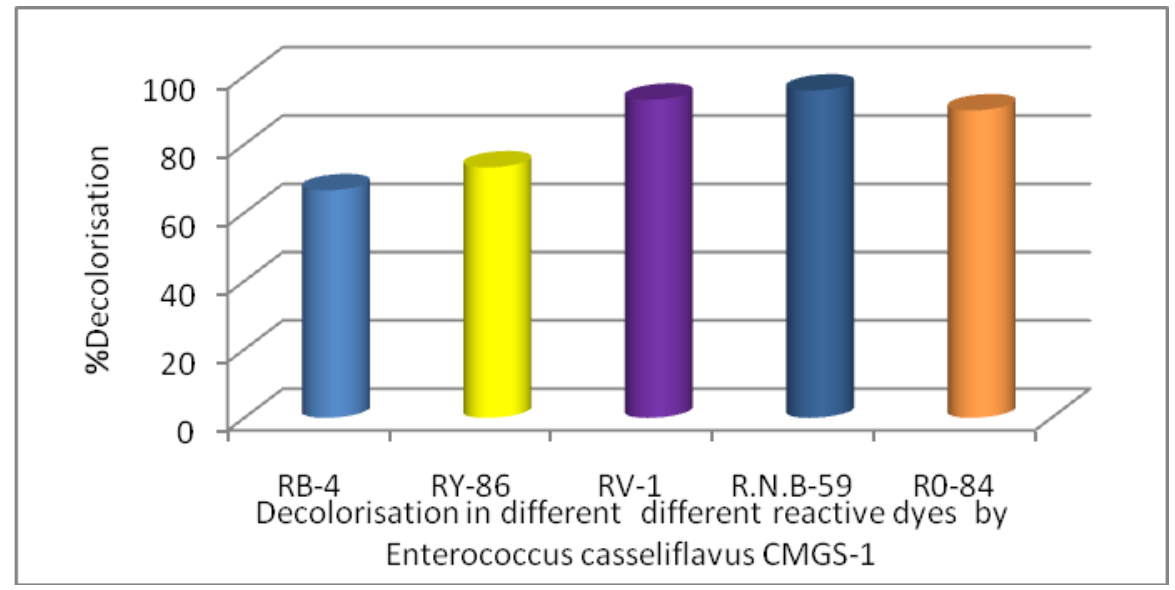


Fig.13 Control peak of reactive red-11

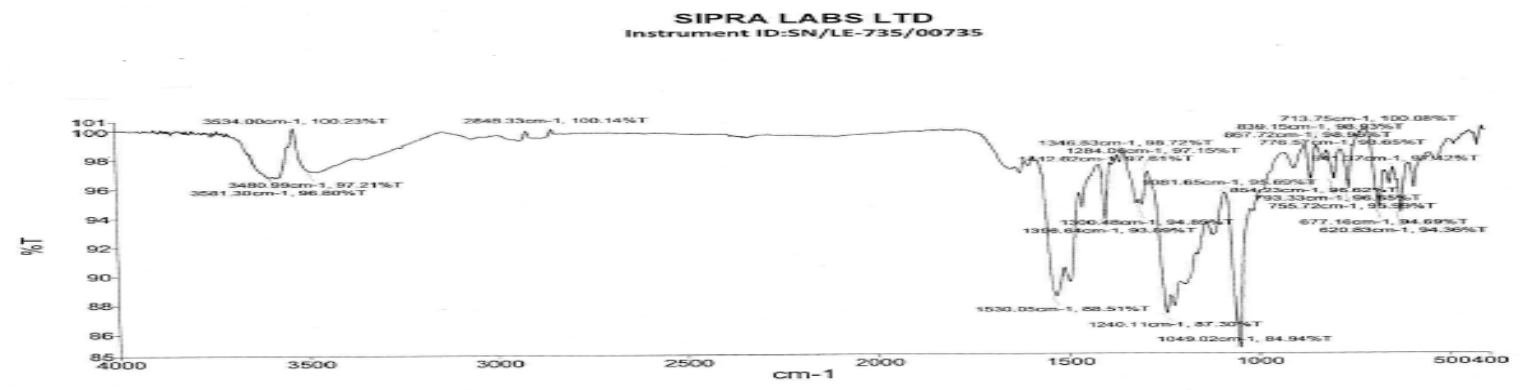

Fig.14 Degraded metabolite peaks of reactive red-11

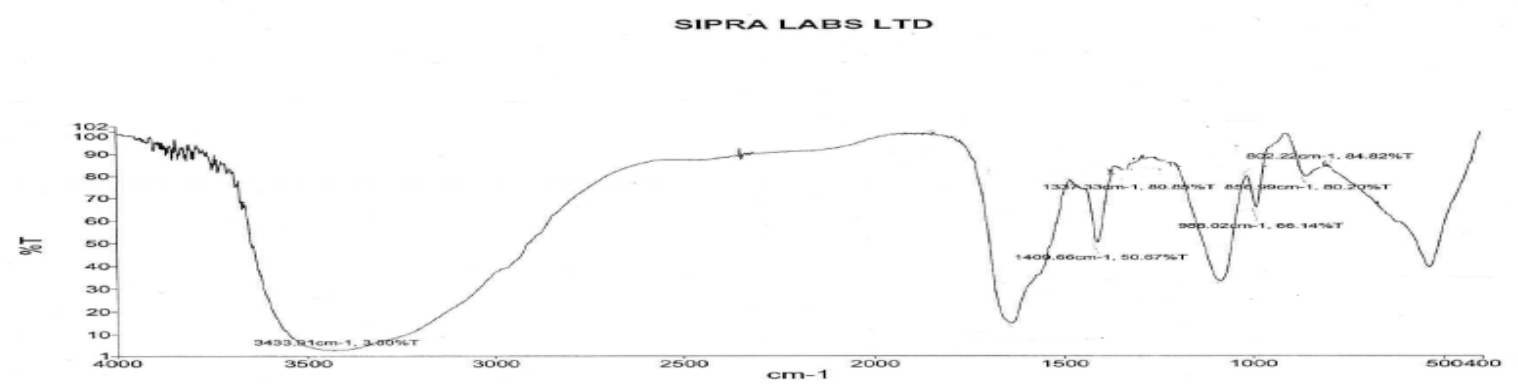

Optimization of the inoculum concentrations

Inoculum concentration helps in the faster decolorisation, isolate CMGS-1 shown optimum inoculum size $5 \mathrm{ml} / 100 \mathrm{ML}$ that is $97.06 \%$ of decolorisation. Inoculum size may depends on the organism report on Decolorization of Red $3 \mathrm{BN}$ by $\mathrm{B}$. cereus optimum inoculum size was $8 \%$ and $B$. megaterium inoculums concentration was 10\%. (Praveen Kumar et al., 2012).

\section{Optimization of various nitrogen sources}

Nitrogen sources makes decolorisation in faster rate, various nitrogen sources were studies, and out of other nitrogen sources yeast extract helps in the effective decolorisation within shorter period of time. Similar with our results, Lysinibacillus RSV-1, strain, shown effective degradation up to $95 \%$ using yeast extract as a nitrogen source and not shown any degradation using ammonium chloride, ammonium sulphate, urea etc., ( Rajeshwari et al., 2011).

Optimization of the yeast extract concentration: To get a highest decolorisation various concentration of yeast extract were selected, our isolate shown $1.0 \mathrm{gm} / \mathrm{L}$ of yeast extract was optimum for the better decolorisation.(kadpan et al., 2000) stated that yeast extract act as dual source of carbon and nitrogen in decolorization of various dyes by bacteria.

\section{Decolorisation of different reactive dyes by Enterococcus casseliflavus strain} CMGS-1

Various reactive dyes were selected for the study of decolorisation and isolate CMGS-1 shown better results in all dyes, they were in reactive blue-4: it was 66.6. in reactive yellow-86-it was 73.3, in reactive violet-1 it was:-93.3\%, in reactive navy blue -59 it 
was95.8, and in reactive orange-84:-it was $90.0 \%$ of decolorisation was studied. Through these results isolate CMGS-1 having wide range of dye degrading capacity.

\section{Biodegradation study by the FT-IR analysis:- Biodegradation Studies By FT- IR}

Control reactive red-11, 23 different peaks were observed, spectroscopy run from 400 to $4000 \mathrm{~cm}^{-1}$ wavelength. The control spectrum of reactive red -11 was found $3581.30 \mathrm{~cm}^{-1}, 3535.00 \quad \mathrm{~cm}^{-1}, 3480.99 \quad \mathrm{~cm}^{-}$ ${ }^{1}$ showing the intermolecular hydrogen bonding, and $-\mathrm{OH}$ Aromatic, $\mathrm{O}-\mathrm{H}$ Streching. $2848.33 \mathrm{~cm}^{-1}$ peak for $\mathrm{N}-\mathrm{H}$ stretching amines. $1530.05 \mathrm{~cm}^{-1}$ for $\mathrm{C}=\mathrm{N}$ Stretching Azo Group, 1081.651049 .02 for $\mathrm{S}=\mathrm{O}$ stretching group, 620.83., 677.16, 839.15, 867.72, 776.57, 793.33,854.23, 755.72 these peak shows dye is in aromatic in nature and C-CL Stretching respectively. and 16hours dye degraded sample peaks observed at- $802.22 \mathrm{~cm}^{-1}, 858.99 \mathrm{~cm}^{-1}, 980.99$ $\mathrm{cm}^{-1}, 1337.33 \mathrm{~cm}^{-1}, 1409.66 \mathrm{~cm}^{-1}, 3433.91$ $\mathrm{cm}^{-1}$ study shown complete degradation of reactive red -11,(Wojnárovits et al., 2005) (Yingling et al., 2008; Rajeshwari et al., 2011; Lambert et al., 1998).

\section{References}

Ali, H. 2010. Biodegradation of Synthetic Dyes-A Review. Water Air Soil Pollut., 213:251-273.

Bheemaraddi, M., Patil, S., Shivannavar, C.T., and Gaddad, S.M. 2014. Isolation and characterization of Paracoccus sp. GSM2 capable of degrading textile azo dye Reactive Violet 5. Scientific World J. 2014:410704. doi:10.1155/ 2014/410704.

Imran, M., Arshad, M., Asghar H.N.,
Asghar, M., Crowley, D.E. 2014. Potential of Shewanella Sp, Strain IFN4 to Decolorize Azo Dyes under optimal conditions. Int J. Agri Boil, 16: 578-64.

Jadhav, S.M,. Yedukar, S.M.S.S. Phugare, and J.P. Jadhav. 2012. Biodegradation studied on Acid violet 19, a Triphenylmethane dye, by Pseudomonas aeruginosa BCH, Clean-Soil Air Water, 40(5), 551-558

Jain K., Shah V., Chapla D. and Madamwar D.,(2012) Decolorization and degradation of azo dye Reactive Violet $5 \mathrm{R}$ by an acclimatized indigenous bacterial mixed culturesSB4 isolated from anthropogenic dye contaminated soil. J. Hazard Mater., 213-214: 378-386.

Kadam, A.A., Telke, A.A., Jagtap, S.S., and Govindwar, S.P. 2011. Decolorization of adsorbed textile dyes by developed consortium of Pseudomonas sp. SUK1 and Aspergillus ochraceus NCIM1146 under solid state fermentation. $J$. Hazard. Mater., 189: 486-94.

Kadpan, I.K., Kargi, F., McMullan, G., and Marchant, R. 2000. Effect of environmental conditions on biological decolorization of textile dye stuff by $C$. versicolor. Enzyme. Microb. Technol., 26: 381-387.

Koichiro Tamura, Glen Stecher, Daniel Peterson, Alan Filipski, and Sudhir Kumar. 2013. MEGA6: Molecular Evolutionary Genetics Analysis Version 6.0, Mol. Biol. Evol., 30(12): 2725-2729.

Lambert, J.B., Shurvell, H.E., Lightner,D.A. and Cooks, R.G. (1998), Organic Structural Spectroscopy, N.J.: Prentice Hall.

Patil, P.S., U.U. Shedbalkar, D.C. Kalyani, and J.P. Jadhav. 2008. "Biodegradation of Reactive Blue 59 by isolated bacterial consortium 
PMB11, J. Industrial Microbiol. Biotechnol., vol. 35, no. 10, pp. 11811190.

Praveen Kumar, G.N., Sumangala, K., Bhatt. 2012. Fungal Degradation of Azo dye- Red 3BN and Optimization of Physico-Chemical Parameters ISCA J. Biol. Sci., 1: 17-24.

Rajeshwari, K., R. Subashkumar and K. Vijayaraman. 2011. Biodegradation of Mixed Textile Dyes Bacterial Strains Isolated from Dye waste Effluent: Res. J. Environ. Toxicol., 5(2): 97-107.

Saitou, M. Nei. 1987. "The neighbor-joining method: a new method for reconstructing Phylogenetic trees". Mol. Biol. Evol., 4(4): 406-425.

Takezaki, N., A. Rzhetsky and M. Nei. 1995. "Phylogenetic test of the molecular clock and linearized trees". Mole. Biol. Evol., 12(5): 823-833.

Tamura, M. Nei, and S. Kumar. 2004. "Prospects for inferring very large phylogenies by using the neighborjoining method". Proceedings of the
National Academy of Sciences of the United States of America, 101(30): 11030-11035.

Usha, M.S., M.K. Sanjay, S.M. Gaddad and C.T. Shivannavar. 2012. Study on degradation of $\mathrm{H}$-acid by Alcaligenes latus isolated from textile industrial effluent, J. Scientific \& Industrial Res., Vol. 71, pp. 235.

Verma, A.K., Dash, R., and Bhunia, P. 2012. A review on chemical coagulation/flocculation technologies for removal of colour from textile wastewaters. J. Environ. Manage, 93: 154-16.

Wojnárovits, L. "Reactivity differences of hydroxyl radicals and hydrated electrons in destructing azo dyes, Radiat. Phys. Chem., vol. 74, pp.

Yingling, Z., Li Shufen, Y., Jinzong, J., Song and Li Qian. 2008. Synthesis and application of novel cross linking polyamine dyes with good dyeing performance, Dyes and Pigments, vol. 76, pp. 508- 514.

\section{How to cite this article:}

Madhuri R. Basutkar, Channappa T. Shivannavar and Subhaschandra M. Gaddad. 2016. Biodegradation of Reactive Red-11 by the Isolate Enterococcus casseliflavus CMGS-1 Strain. Int.J.Curr.Microbiol.App.Sci. 5(11): 565-578. doi: http://dx.doi.org/10.20546/ijcmas.2016.511.067 